\title{
Potentiometric FIA System with Reactor Based on Natural Urease Source and Tubular Detector of Ammonium Ions. Determination of Urea in Fertilizers
}

\author{
Laércio R. JÚnIoR*, Graciliano de Oliveira Neto*†, José L. F. C. LIMA**, \\ Maria C. B. S. M. Montenegro** and Valdinete L. SilvA*** \\ *Instituto de Química, UNICAMP, POBox 6154, 13083-970, Campinas, SP, Brazil \\ ** Faculdade de Farmácia, Universidade do Porto/CEQUP/4000 Porto, Portugal \\ ***Faculdade de Engenharia Química, UFPe, Recife, Brazil
}

\begin{abstract}
An FIA system was developed to analyze urea by monitoring ammonium ions generated by enzymatic degradation with a tubular ion-selective electrode containing nonactin on polyvinyl chloride (PVC) membrane. As an urease source, $120 \mathrm{mg}$ of the leguminous canavalia brasiliensis were immobilized in an enzymatic reactor with glutaraldehyde. Ammonium ions are converted to ammonia by an alkaline solution, $1 \mathrm{~mol}^{-1} \mathrm{NaOH}$, and permeates through a polytetrafluoroethylene membrane until the detector. The method can be used in an urea concentration range of $2.5 \times 10^{-4}$ to $2.5 \times 10^{-3} \mathrm{~mol} \mathrm{l}^{-1}\left(25.0^{\circ} \mathrm{C}\right)$. Analysis of $25 \mu \mathrm{l} \mathrm{commercial} \mathrm{samples} \mathrm{of} \mathrm{fertilizers,} \mathrm{showed} \mathrm{a} \mathrm{relative} \mathrm{error} \mathrm{of} 0.2 \%$ with a high selectivity to the species present.
\end{abstract}

Keywords Fertilizer, urea determination, canavalia brasiliensis, flow injection analysis, potentiometry

Several enzyme immobilized techniques have been employed to prepare sensors for the determinations by flow injection analysis (FIA). ${ }^{1,2}$ The physical and chemical immobilization of urease and the construction of sensors for urea have been published. ${ }^{3,4}$ Biosensors can also be prepared using materials which contain the enzyme naturally immobilized in vegetal cells. Plant tissues have been used in electrochemical sensors for tyrosine $^{5}$ and glutamate. ${ }^{6}$

The enzymatic methods are especially suited for urea determination because of a high selectivity in relation to the substrate of interest. Another important factor in enzymatic determination is the low cost per analysis, when natural alternative sources are used instead of isolated enzymes which are not always easy to obtain, even more at high degrees of purity. The limiting factor in these processes is the diffusion of the substrate through the cellular membrane, which directly determines the catalytic activity of the material used.

The enzymatic biosensors are currently being used for a large number of analytical determinations, particularly in clinical analyses. At present, the principal use is in the determination of glucose levels in blood using the glucose oxidase enzyme and an oxygen amperometric electrode. Biosensors can be used to analyze urea, oxalate, salicylate, cholesterol and some metabolites of clinical diagnostic interest. ${ }^{7}$ The industrial employment

† To whom correspondence should be addressed. of enzymatic sensors is increasing, mainly in food industries such as sugar and alcohol.

Ionophores, ligands which selectively associate themselves with ions, were especially studied in potentiometric analysis, based on the potential difference associated with the interaction. Typically they are macrocyclic molecules with an ion linked in a cavity which is well defined. The selectivity is based on the relation between the dimensions of the ion and the ligand site. Crown ethers constitute the best known class, although other types of molecules, of synthetic or natural occurrence, act as ionophores. In addition to the elevated selectivity, neutral ionophores used in ion-selective electrodes are not subjected to protonation; consequently, the equilibrium constants are not affected by the $\mathrm{pH}$ value, as was the case for nonactin ${ }^{8}$ ionophore used in this present work. This paper describes an FIA system developed to determine urea in fertilizer samples, using a vegetal source of urease ${ }^{9}$ and potentiometric detection with a tubular electrode ${ }^{10,11}$ containing the nonactin ionophore in a PVC membrane.

\section{Experimental}

\section{Apparatus}

The potential difference measurements were obtained with a $\mathrm{pH} /$ ion analyzer OP-271 $( \pm 0.1 \mathrm{mV})$, a double junction electrode OP-0820P of $\mathrm{Ag} \mid \mathrm{AgCl}$ with $1 \mathrm{~mol} \mathrm{l}^{-1}$ 


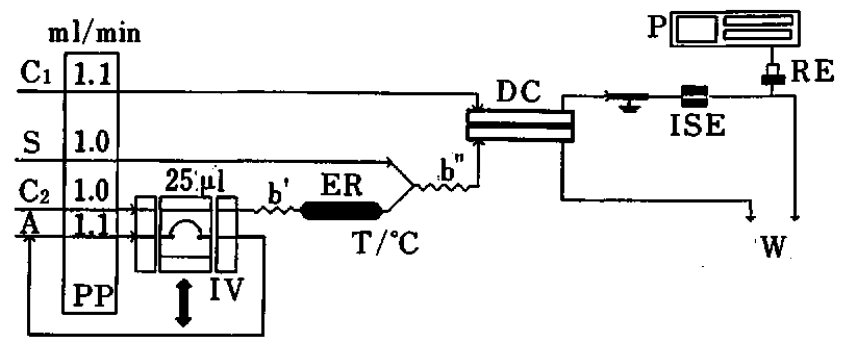

Fig. 1 Flow injection manifold for the determination of urea in fertilizers using urease from canavalia brasiliensis and potentiometric detection. $\mathrm{C}_{1}=$ carrier 1 , solution of $0.05 \mathrm{~mol} \mathrm{l}^{-1} \mathrm{Ca}\left(\mathrm{NO}_{3}\right)_{2} ;(\mathrm{pH}=5.0) \mathrm{C}_{2}=$ carrier 2, solution of $10^{-3} \mathrm{~mol} \mathrm{l}^{-1} \mathrm{Na}_{2} \mathrm{H}_{2} \mathrm{EDTA}$; $\mathrm{S}$, sample (urea); A, solution of $1.0 \mathrm{~mol} \mathrm{l}^{-1} \mathrm{NaOH}$; PP, peristaltic pump; DC, diffusion cell (membrane of PTFE); ER, enzymatic reactor (canavalia brasiliensis immobilized with glutaraldehyde); ISE, tubular ion-selective electrode to $\mathrm{NH}_{4}{ }^{+} ; \mathrm{RE}$, reference electrode; IV, injection valve; $P$, potentiometer $( \pm 0.1 \mathrm{mV}) ; \mathrm{T}$, temperature sensor $\left( \pm 0.1^{\circ} \mathrm{C}\right)$; $\mathrm{W}$, fluid discharge.

$\mathrm{Ca}\left(\mathrm{NO}_{3}\right)_{2}$ in the exterior compartment and a temperature detector OP-0003P. All components were manufactured by Radelkis (Hungary). Also, a thermostatic bath, Colora type $\mathrm{KT} 10 \mathrm{~K}\left( \pm 0.1^{\circ} \mathrm{C}\right)$, an $\mathrm{XY}$ recorder Model RB-101 and a spectrophotometer MICRONAL, Model B-382, were used. A tubular ammonium ionselective electrode ${ }^{12,13}$, containing nonactin ionophore in a PVC matrix of high molecular weight, was assembled with a injection flow system to quantify urea. The ammonia generated permeates through a $1 \mathrm{moll}^{-1}$ $\mathrm{NaOH}$ solution to the potentiometric detector (Fig. 1).

\section{FIA manifold}

In this system (Fig. 1), the sample carrier solution, $10^{-3} \mathrm{~mol} \mathrm{l}^{-1} \mathrm{Na}_{2} \mathrm{H}_{2}$ EDTA, is transported by a peristaltic pump, Ismatec Model mp13GJ-14, to a diffusion cell (Fig. 2) with a PTFE membrane. A manual injector was used to insert the urea solutions into the system via carrier solution. Two more ducts are used, one to carry a $0.05 \mathrm{~mol} \mathrm{l}^{-1} \mathrm{Ca}\left(\mathrm{NO}_{3}\right)_{2}$ solution to the detector after first passing one of the sides of the diffusion cell and the other to carry an alkaline solution to the confluence of the three ducts. The enzymatic reactor consists of a Tygon tube of $6.0 \mathrm{~cm}$ length and $2.5 \mathrm{~mm}$ internal diameter. The chemically immobilized enzymatic material was inserted in small pieces $(120 \mathrm{mg})$ in such a way that it did not obstruct the passage of the liquid.

The reference electrode was positioned $10.0 \mathrm{~cm}$ after the indicator electrode. Finally, two coils were used in the system: one of $45.0 \mathrm{~cm}$ to the thermostatic control of solutions and the other of $50.0 \mathrm{~cm}$ to promote the reaction of the alkaline solution with the ammonium ions. To minimize the noises in the system, a stainlesssteel tube of $0.5 \mathrm{~mm}$ internal diameter and $20.0 \mathrm{~mm}$ length was inserted before the indicator electrode. Tygon tubes and polyethylene tubes for the other

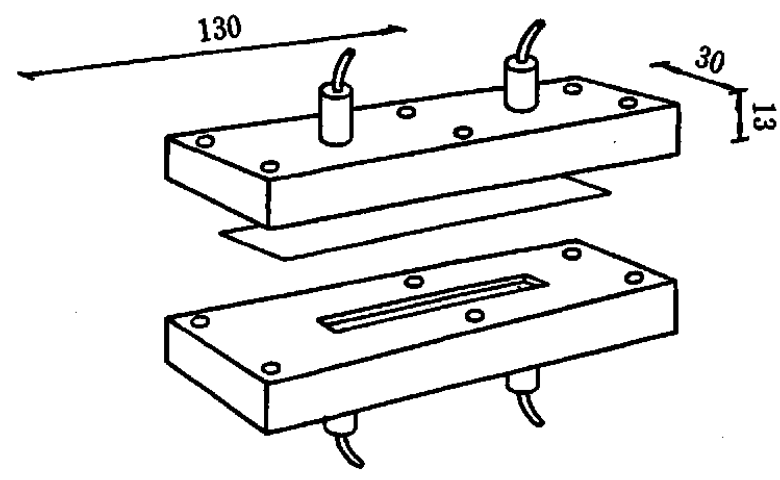

Fig. 2 Scheme of the diffusion cell in acrylic base. The internal dimensions are: $1.0 \times 3.0 \times 103.0 \mathrm{~mm}^{3}$.

connections were used to pump the solutions in the system; all tubes were of $0.8 \mathrm{~mm}$ internal diameter.

\section{Reagents and chemicals}

The standard solutions of urea, with concentrations in a range of $0.25 \times 10^{-3}$ to $5.0 \times 10^{-3} \mathrm{moll}^{-1}$, were prepared by weighing $( \pm 0.01 \mathrm{mg})$ and diluting in $10^{-3} \mathrm{~mol} \mathrm{l}^{-1}$ $\mathrm{Na}_{2} \mathrm{H}_{2}$ EDTA. All reagents used to prepare the solutions were analytical grade. To prepare the tubular potentiometric electrode, a nonactin ionophore (Fluka) solution was mixed with the plasticizer solvent bis-2(ethylhexyl)adipate (Fluka) at 3.0\% (w/v). PVC, of high molecular weight (Fluka), in tetrahydrofuran (THF) at $5.0 \%(\mathrm{w} / \mathrm{v})$ was added to this solution in a proportion of $30.0 \%$ of sensor mixture to $70.0 \%$ of the solution with PVC.

\section{Electrode preparation}

The solution of the ionophore and PVC was dropped directly onto the supporting conductor of the tubular electrode, formed from a mixture of Araldite (epoxy resin) containing graphite powder $(2.0 \mu \mathrm{m}$, Fluka), to make it conductive. The electrode has a length of $6.0 \mathrm{~mm}, 10.0 \mathrm{~mm}$ external diameter and $1.5 \mathrm{~mm}$ internal diameter. After the THF has dried, the polymerized membrane containing the ionophore remains attached to the walls of the electrode and its aperture was reduced to an internal diameter of $c a .0 .8 \mathrm{~mm}$.

\section{Enzymatic immobilization}

The leguminous canavalia brasiliensis ${ }^{9}$ was immobilized by mixing $120 \mathrm{mg}$ of the powdered ( $80 \mathrm{mesh}$ ) biocatalytic material with $50 \mu \mathrm{l}$ of $0.2 \mathrm{~mol} \mathrm{l}^{-1}$ Tris- $\mathrm{HCl}(\mathrm{pH}=6.7)$ buffer and $50 \mu \mathrm{l}$ of glutaraldehyde at $12.5 \%(\mathrm{v} / \mathrm{v}) ;{ }^{14}$ the mixture was homogenized and dried at room temperature for $24 \mathrm{~h}$. Then, the material was cut into small fillets and loosely packed in the previously described Tygon tube to allow the liquid to flow freely through the tube. The material was then conditioned for an additional $24 \mathrm{~h}$ in $0.2 \mathrm{~mol} \mathrm{l}^{-1}$ Tris- $\mathrm{HCl}$ buffer at $4^{\circ} \mathrm{C}$. 


\section{Fertilizer samples}

A commercial fertilizer containing $30 \%$ total nitrogen as urea, $10 \%$ phosphorous as $\mathrm{P}_{2} \mathrm{O}_{5}$ and $10 \%$ potassium as $\mathrm{K}_{2} \mathrm{O}$ was analyzed using the flow potentiometric system. As a reference for urea analysis, a spectrophotometric method with Nessler's reagent ${ }^{15}$ was used. Initially, a calibration curve for urea solutions in $\mathrm{Na}_{2} \mathrm{H}_{2}$ EDTA $1 \%$ $(\mathrm{pH}=6.5)$ in the range of $5.0 \times 10^{-4}$ to $2.5 \times 10^{-2} \mathrm{~mol} \mathrm{I}^{-1}$ was obtained using the following technique: $1.0 \mathrm{ml}$ urea samples were transferred to tubes containing $2.0 \mathrm{ml}$ distilled water and $120 \mathrm{mg}$ of the leguminous in powder form. After mixing well, the tubes were placed in a thermostatic bath at $25.0^{\circ} \mathrm{C}$ for $5 \mathrm{~min}$. To develop the colored compound, $1.0 \mathrm{ml}$ of the prepared sample were transferred to new tubes and then $15.0 \mathrm{ml}$ of distilled water and $1.0 \mathrm{ml}$ of freshly prepared Nessler's reagent was added as described previously. ${ }^{15}$ After mixing, the solutions were again placed in the thermostatic bath at $25.0^{\circ} \mathrm{C}$ for 5 additional minutes. The absorbance was read in polyethylene cells of $1.0 \mathrm{~cm}$ of optical path at the maximum absorption wavelength of $436 \mathrm{~nm}$.

\section{Results and Discussions}

The urea analysis is based on an enzymatic degradation of urea by canavalia brasiliensis as a urease source with high catalytic activity. The ammonium ions produced are converted to ammonia by reaction with a strong base and permeate to the detector. The reactions involved in the process are represented by the equations:

$$
\begin{aligned}
& \left(\mathrm{NH}_{2}\right)_{2} \mathrm{CO}+3 \mathrm{H}_{2} \mathrm{O} \stackrel{\text { urease }}{\rightleftharpoons} 2 \mathrm{NH}_{4}^{+}+\mathrm{CO}_{2}+2 \mathrm{OH}^{-} \\
& \mathrm{NH}_{4}^{+}+\mathrm{OH}^{-} \rightleftharpoons \mathrm{NH}_{3}+\mathrm{H}_{2} \mathrm{O} K_{\mathrm{b}}=1.8 \times 10^{-5}
\end{aligned}
$$

The generated ammonia passes then into the diffusion cell where it is converted to ammonium ions. The use of a carrier solution which favors the displacement of ammonia equilibrium to the ionic form is recommended. This can be conveniently achieved with a $0.05 \mathrm{~mol} \mathrm{l}^{-1}$ $\mathrm{Ca}\left(\mathrm{NO}_{3}\right)_{2}$ solution at $\mathrm{pH}=5.0$, since the ionic strength of the resulting solution is controlled without a significant interference of calcium ions in the response of ion-selective electrode ${ }^{13}$ (low coefficient of potentiometric selectivity). The chemical immobilization of

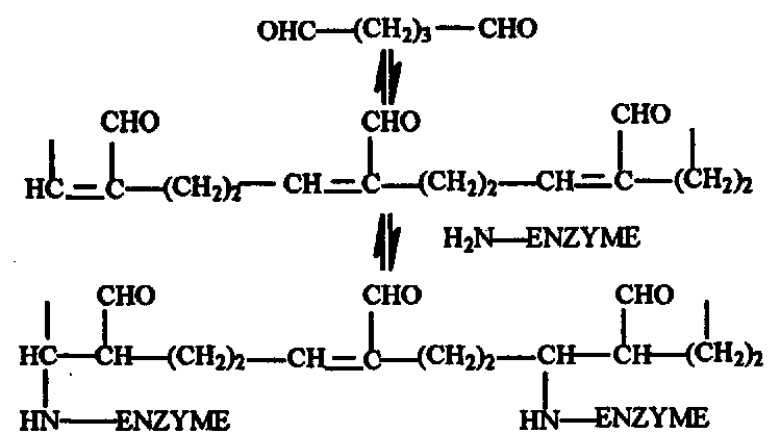

enzymatic source is represented below. ${ }^{16}$ The immobilization results in a greater physical and chemical stability of the catalytic material due to the cross-linkages formed with glutaraldehyde bifunctional reagent and the active sites of the enzyme are more accessible for the enzymatic reaction. The material may be reused several times, but must be kept in an appropriate buffer and under refrigeration: $0.2 \mathrm{~mol} \mathrm{l}^{-1}$ Tris- $\mathrm{HCl}$ and $4^{\circ} \mathrm{C}$.

A partial loss of enzymatic activity was noted during the immobilization reaction. However, it is possible to optimize the concentration of glutaraldehyde as well as the quantity of enzymatic material in order to have an appropriate response. In the present work, the use of $120 \mathrm{mg}$ of biocatalytic material resulted in a washing time of $15 \mathrm{~s}$ in the range of urea concentrations used. A stable base line with no excessive saturation effects of the enzyme and a good correlation between the obtained values of the potential difference and concentration of urea was observed.

To avoid saturation effects of the enzyme-substrate complex, with increase of the response time of the system, the volume used for the injection of the samples was optimized. A volume of $25 \mu l$ gave stable potentiometric signals with high reproducibility in the urea concentration range used. Smaller volumes did not present any response with the prepared enzymatic column, probably due to absorption of the substrate in the immobilized material.

The urea solutions were prepared in the presence of $\mathrm{Na}_{2} \mathrm{H}_{2}$ EDTA since metals such as $\mathrm{Fe}^{2+}, \mathrm{Ni}^{2+}$ and $\mathrm{Co}^{2+}$ act as urease inhibitors and deactivate the enzyme. Some active sites of urease are formed by $\mathrm{SH}^{-}$groups which may be deactivated by the reaction with these metals. ${ }^{17}$

\section{Determination of urease activity in canavalia brasiliensis}

The catalytic activity of urease present in several legumes was quantified by monitoring the $\mathrm{NH}_{4}{ }^{+}$ions from the hydrolysis of urea with an ammonium ionselective electrode. The urease activity, or one unit of activity, is defined as the quantity of enzyme which catalyzes the production of $1.0 \mu \mathrm{mol}$ of $\mathrm{NH}_{4}{ }^{+}$per minute and per mg of enzymatic material under the experimental conditions described below.

Firstly, a calibration curve for $\mathrm{NH}_{4} \mathrm{Cl}$ in the range of $5.0 \times 10^{-4}$ to $5.0 \times 10^{-1} \mathrm{~mol} \mathrm{l}^{-1}$ was obtained $\left(r^{2}=0.99996\right)$, which can be represented by the equation:

$$
\Delta E=58.52( \pm 0.03) \log \left[\mathrm{NH}_{4}^{+}\right]+172.71( \pm 0.05)
$$

The legumes in powder form, $12 \mathrm{mg}$ per $\mathrm{ml}$ of substrate at $25.0^{\circ} \mathrm{C}$, used in a $0.2 \mathrm{~mol}^{-1}$ Tris- $\mathrm{HCl}$ buffer, was added to urea solutions of different concentrations and the amount of $\mathrm{NH}_{4}{ }^{+}$ions was determined per minute (Fig. 3b), using the ammonium ion-selective electrode. The $\Delta E$ values obtained from curves of potential difference versus time (Fig. 3a) were utilized in the Eq. (3), so the ammonium molar concentration generated in the enzymatic reaction was determined. It was fixed during the period of $30 \mathrm{~s}$ where the enzymatic kinetics is 


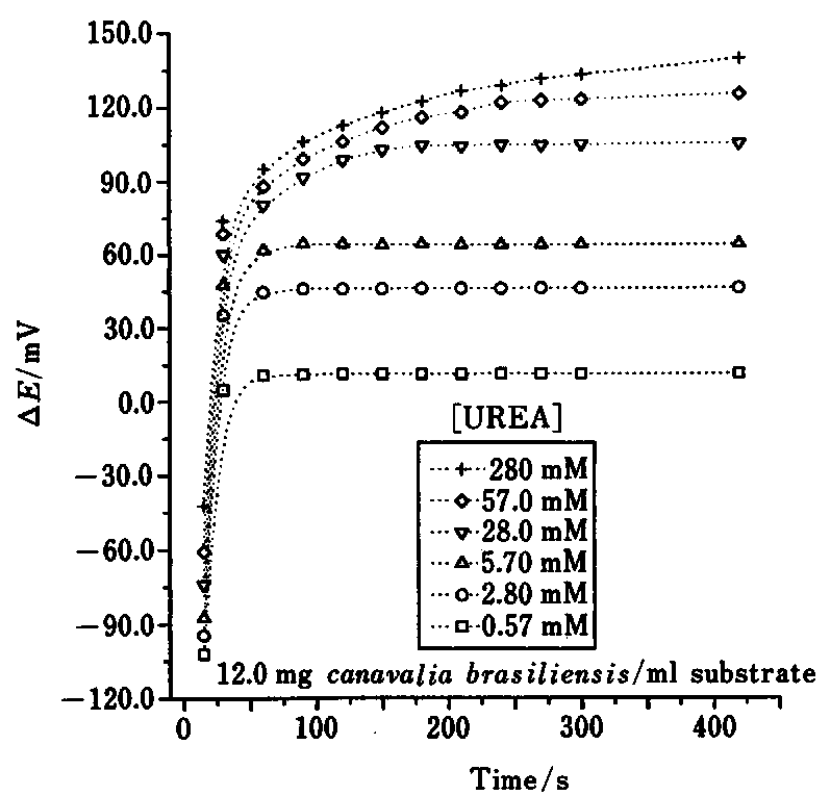

Fig. 3a Potential difference versus time curves, using $12.0 \mathrm{mg}$ $\mathrm{ml}^{-1}$ of canavalia brasiliensis in $10.0 \mathrm{ml}$ of urea solutions (0.2 $\mathrm{mol} \mathrm{l}^{-1}$ Tris-HCl, $\mathrm{pH}=6.7$, buffer $) . \quad T=25.0^{\circ} \mathrm{C}$.

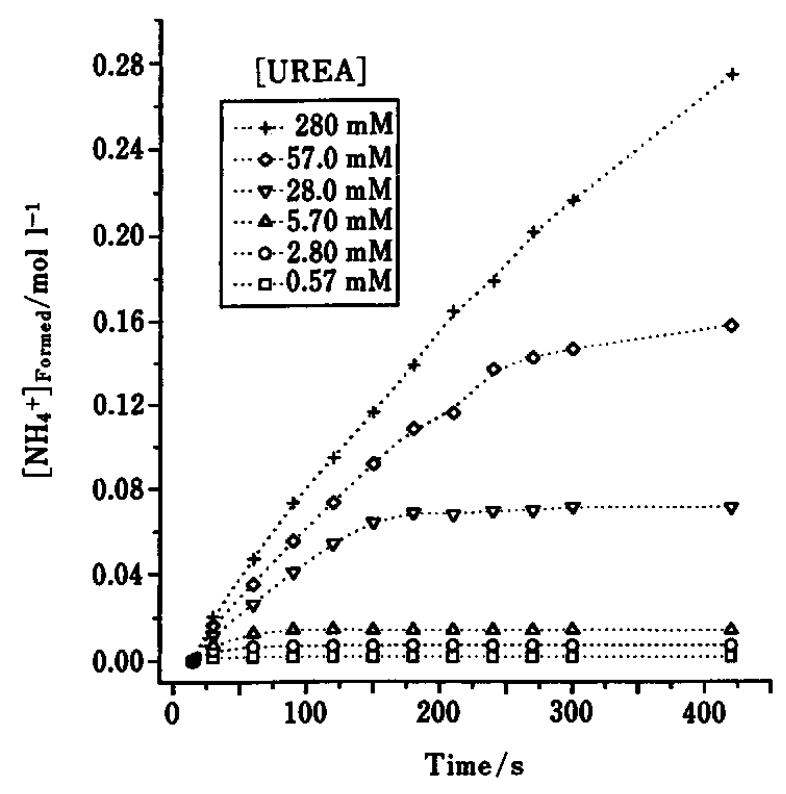

Fig. 3b Molar concentration of ammonium ions formed versus time curves, using $12.0 \mathrm{mg} \mathrm{m}^{-1}$ of canavalia brasiliensis in $10.0 \mathrm{ml}$ of urea solutions $\left(0.2 \mathrm{~mol} \mathrm{l}^{-1}\right.$ Tris- $\mathrm{HCl}, \mathrm{pH}=6.7$, buffer). $\quad T=25.0^{\circ} \mathrm{C}$.

first order for the urease.

The activity of the glutaraldehyde-immobilized urease is the same as that for the naturally immobilized urease. The glutaraldehyde only protects the lixiviation of the ground meal.

The concentration range of urea is narrower than that of ammonium ions because for higher concentrations of
Table 1 Enzymatic activities for different sources of enzyme urease (potentiometric method)

\begin{tabular}{ccccc}
\hline \multirow{2}{*}{$\begin{array}{c}\text { [Urea]/ } \\
10^{-3} \mathrm{~mol} \mathrm{1}^{-1}\end{array}$} & \multicolumn{3}{c}{ Vegetal source $(12.0 \mathrm{mg} / \mathrm{ml}$ substrate) } \\
\cline { 2 - 5 } & $\begin{array}{c}\text { Pure } \\
\text { urease }^{\mathrm{a}}\end{array}$ & $\begin{array}{c}\text { canavalia }^{\text {ensiformis }}{ }^{9} \\
\text { canavalia }^{\text {maritima }}\end{array}$ & $\begin{array}{c}\text { canavalia } \\
\text { brasiliensis }\end{array}$ \\
\hline 0.57 & 8.52 & 0.12 & 0.32 & 0.23 \\
2.80 & 9.42 & 0.14 & 0.47 & 0.73 \\
5.70 & 10.2 & 0.15 & 0.49 & 1.15 \\
28.0 & 10.3 & 0.19 & 0.60 & 2.00 \\
57.0 & 10.6 & 0.24 & 0.77 & 2.83 \\
280 & 10.7 & 0.86 & 1.05 & 3.33 \\
\hline
\end{tabular}

a. Urease obtained from Sigma, type IIC, Cat. \#U-8876, with $12000 \mathrm{U} / \mathrm{g}$ protein.

$1 \mathrm{U}=1.0 \mu \mathrm{mol} \mathrm{NH} 4^{+} / \mathrm{min} \mathrm{mg}$ biocatalytic material $\left(T=25.0^{\circ} \mathrm{C}\right)$.

urea there is saturation of the enzyme active sites. The specific activity for urease was found to be $4.72 \mathrm{U}$ per $\mathrm{mg}$ of protein, measured as described by Chaney and Marbach ${ }^{18}$ and Folch and Stanley. ${ }^{19}$ It means that the reactor has about $560 \mathrm{U}$ of urease. The activities of three different vegetal sources ${ }^{9}$ and of pure urease are shown in the Table 1. The legume canavalia brasiliensis showed a high catalytic activity in relation to the other species studied.

\section{Effect of temperature on the urea hydrolysis}

The catalytic activity of enzymatic reactions usually increases up to a certain temperature and then decreases due to enzyme denaturation. This optimum temperature varies with the enzyme and with the conditions of the analysis. Usually, this temperature does not exceed $40^{\circ} \mathrm{C}$, although some enzymatic structures are able to resist higher temperatures, as the ones found in some thermophilic bacteria.

The analytical signal was monitored as a function of the temperature $\left(25.0,29.0,33.0\right.$ and $\left.37.0^{\circ} \mathrm{C}\right)$. In these measurements, a urea solution of $10^{-3} \mathrm{moll}^{-1}$ was used and the enzymatic reactor containing $120 \mathrm{mg}$ of immobilized catalytic material was immersed in a thermostatic bath $\left( \pm 0.1^{\circ} \mathrm{C}\right)$. For each temperature, three injections of urea solution were made, and the response was very reproducible with an estimated standard deviation is $\pm 0.4 \mathrm{mV}$. A $10 \%$ increase in the signal was obtained at 33.0 and at $37.0^{\circ} \mathrm{C}$ in relation to other chosen temperatures. As the differences are not very large, it is possible to work at $25.0^{\circ} \mathrm{C}$, although temperatures up to $37.0^{\circ} \mathrm{C}$ may be used. About $89 \%$ of urea from the fertilizer sample is converted to ammonium ions. All of that is transformed in ammonia by reaction with alkaline solution, which permeates through the PTFE membrane and is detected again as ammonium ions in the tubular detector.

Optimization of FIA system for urea determination in fertilizers

Based on the experimental results, the experimental 


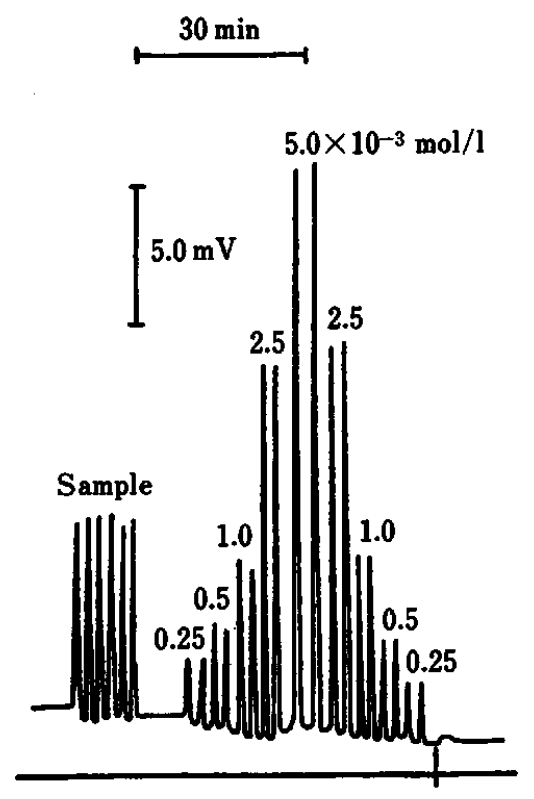

Fig. 4 Flow injection recordings obtained for urea solutions (calibration curve) and fertilizer sample: sample volume, $25 \mu \mathrm{l}$; recorder sensitivity, $50.0 \mathrm{mV}$; paper speed: $4.0 \mathrm{~cm} \mathrm{~h}^{-1}$; $120 \mathrm{mg}$ of biocatalytic material immobilized; $T=25.0^{\circ}$. Sample concentration: $2.0 \times 10^{-3} \mathrm{~mol} \mathrm{l}^{-1}(n=6)$.

conditions for the potentiometric urea determination were optimized. A sample volume of $25 \mu \mathrm{l}$ is sufficient to generate a potential difference proportional to the injected substrate concentration. The representative calibration curve presented in Fig. 4 shows a linear dependence of the height of the potentiometric signal with the urea concentration in the range of $5.0 \times 10^{-4}$ to $5.0 \times 10^{-3} \mathrm{~mol} \mathrm{l}^{-1}$. The relative deviation of the peaks was $0.1 \%$. The least squares method showed a good correlation $\left(r^{2}=0.99194\right)$ for the values of the potential difference, $\Delta E(\mathrm{mV})$, and logarithmic urea concentration, given by:

$$
\Delta E=31.01( \pm 0.05) \log [\mathrm{UREA}]+107.06( \pm 0.04)
$$

\section{Accuracy of the proposed method}

To evaluate the precision of the procedure utilized in this work, the determination of urea in a commercial fertilizer was compared with that obtained by an extensively used spectrophotometric method. The Nessler's method is normally employed to quantify ammonia in diluted solutions, of the order of $0.1 \mathrm{mg} \mathrm{l}^{-1}$. Ammonia liberated by the enzymatic hydrolysis of urea reacts with an alkaline mercurate(II) tetraiodine solution, producing a colored compound with maximum absorption at the wavelength of $436 \mathrm{~nm}$ :

$$
2 \mathrm{~K}_{2}\left[\mathrm{HgI}_{4}\right]+2 \mathrm{NH}_{3} \rightleftharpoons \mathrm{NH}_{2} \mathrm{Hg}_{2} \mathrm{I}_{3}+4 \mathrm{KI}+\mathrm{NH}_{4} \mathrm{I}
$$

The results obtained for the urea and total nitrogen in a sample of fertilizer by both methods are presented in Table 2. The value obtained by the spectrophotometric
Table 2 Correlation of the results for urea determination in fertilizers by spectrophotometric and FIA-potentiometric methods

\begin{tabular}{lccc}
\hline \multirow{2}{*}{$\begin{array}{c}\text { Urea } \\
\text { sample }\end{array}$} & $\begin{array}{c}\text { Nominal } \\
\text { value }\end{array}$ & Spectrophotometric & $\begin{array}{c}\text { FIA- } \\
\text { potentiometric }\end{array}$ \\
\cline { 3 - 4 } Fertilizer & $65 \%$ & $64.8 \pm 0.3 \%^{\mathrm{a}}$ & $65.2 \pm 0.2 \%^{\mathrm{a}}$ \\
\hline a. Relative standard deviation estimative for 6 determinations.
\end{tabular}

method was $(64.8 \pm 0.3) \%$ of urea, which corresponds to $(29.8 \pm 0.3) \%$ total nitrogen per gram of fertilizer. This determination agrees with that obtained by the FIApotentiometric method within the experimental error.

\section{Enzymatic reactor lifetime}

The $6.0 \mathrm{~cm}$ column with biocatalytic material, prepared as described in the experimental section, was used for two months with weekly injections of $10^{-3} \mathrm{~mol} \mathrm{l}^{-1}$ urea solutions without any loss of its enzymatic activity as evaluated by the potentiometric signal. The column was kept under refrigeration $\left(4^{\circ} \mathrm{C}\right)$ in $0.2 \mathrm{moll}^{-1}$ Tris$\mathrm{HCl}$ buffer to avoid any drying-up of the material when not in use. The use of an FIA system associated with a diffusion cell eliminates the problems associated with colored species, as is the case of fertilizer, and with turbidity; the carrier solutions used in the system are easy to prepare and do not need any buffer.

The sample showed a value of $(65.4 \pm 0.2) \%$ of urea, that corresponds to $(30.2 \pm 0.2) \%$ in total nitrogen per gram of fertilizer for the potentiometric method, which is in the range specified by the producer with a $2 \%$ variation margin. So, the method may be used to quantify urea, becoming an alternative analytical method. The analytical method is simple, fast and precise, and the system shows a good linearity in the concentration interval used. One of the most desirable aspects of this method is the low cost of the leguminous material used as the source of natural enzymes to produce catalytic activity.

The authors wish to acknowledge with thanks the financial support received from JNICT through project No. PEAM/ CTAI/269-93. We also thank Dr. Fred Y. Fujiwara for reviewing the English text. L. R. Jr. also is grateful for the scholarship received from CAPES.

\section{References}

1. B. A. Peterson, Anal. Chim. Acta, 209, 239 (1988).

2. L. C. Faria, C. Pasquini and G. O. Neto, Analyst [London], 116, 357 (1991).

3. J. Deng, Y. Fang and R. Cai, Electroanalysis, 3, 767 (1991).

4. E. M. Fabregas and S. Alegret, J. Chem. Educ., 71, A67 (1994).

5. F. Schubert, U. Wallenberg and F. W. Scheller, Biotechnol. Lett., 5, 239 (1983). 
6. S. Kuiyama and G. A. Rechnitz, Anal. Chim. Acta, 131, 91 (1981).

7. N. M. Ratellif, Anal. Chim. Acta, 239, 257 (1990).

8. G. J. Moody and J. D. R. Thomas, Analyst [London], 113, 497 (1988)

9. V. L. Silva, G. O. Neto, L. M. Aleixo and O. E. S. Godinho, Electroanalysis, 6, 593 (1994).

10. J. L. F. C. Lima, M. C. B. S. M. Montenegro and A. M. R. Silva, J. Flow Injection Anal., 7, 19 (1990).

11. J. A. Chamarro, J. Bartrolí, S. Jun, J. L. F. C. Lima and M. C. B. S. M. Montenegro, Analyst [London], 118, 1527 (1993).

12. S. Alegret, J. Bartrolí and E. M. Fabregas, Analyst [London], 114, 1443 (1989).
13. L. Rover Jr., G. O. Neto, J. L. F. C. Lima and M. C. B. S. M. Montenegro, Quím. Nova, 19, 549 (1996).

14. D. R. Walt and V. I. Agayn, Tr. Anal. Chem., 13, 425 (1994).

15. A. I. Vogel, "Textbook of Quantitative Inorganic Analysis", 4th ed., p. 730, John Wiley \& Sons, New York, 1987.

16. W. H. Scouten, "Solid Phase Biochemistry", Vol. 66, p. 260, John Wiley \& Sons, New York, 1983.

17. G. B. Kistaiakowsky and W. H. R. Shaw, J. Am. Chem. Soc., 75, 2751 (1951).

18. A. L. Chaney and E. P. Marbach; Clin. Chem., 8, 130 (1960).

19. J. Folch and G. S. Stanley, J. Biol. Chem., 266, 409 (1957).

(Received January 13, 1997) (Accepted May 23, 1997) 